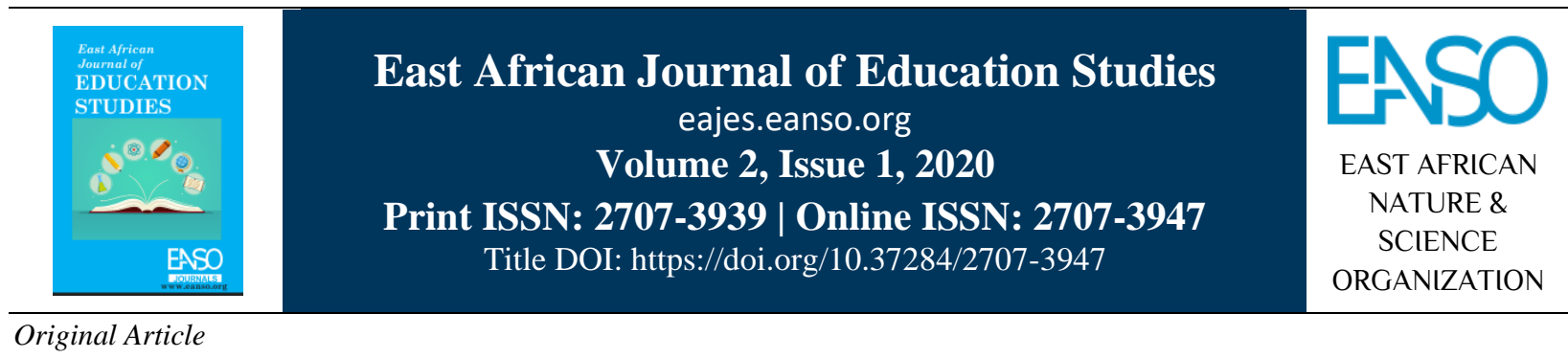

\title{
Influence of School Feeding Programme on Acquisition of Competencies in Class Activities Among Pre-Primary School Pupils in Belgut Sub-County, Kenya
}

\author{
Benson Kiprotich Langat ${ }^{* 1}$, Dr. Benedicta Aiyobei Tabot ${ }^{1} \&$ Dr. Joseph Rotumoi ${ }^{1}$ \\ ${ }^{1}$ University of Kabianga, P. O. Box 2030 - 20200, Kericho, Kenya \\ *ORCID: https://orcid.org/0000-0003-2506-4927; Author for Correspondence email: langatbenson84@ gmail.com.
}

Article DOI: https://doi.org/10.37284/eajes.2.1.259

\section{Date Published: ABSTRACT}

30 December 2020 Feeding programmes are critical for quality education to be realized in all learning institutions starting from Pre-primary to higher levels globally. When

Keywords: there is no provision of meals to children in school, they lack the energy to

School Feeding

Programme,

Competency in Class

Activity,

Descriptive Survey

Design,

Pre-Primary School

Pupils,

Belgut Sub-County. concentrate in classroom and co-curricular activities. It also weakens their intellectual ability and may hinder the development of competencies among pre-primary school learners. In this study, it was assumed that the provision of meals to pupils in school influences the acquisition of competencies among the learners. The purpose of this study, therefore, was to establish the influence of School Feeding Programmes on the acquisition of competencies in classroom activities among the learners in pre-primary schools in Belgut Sub-County, Kericho County. The study was guided by Abraham Maslow's theory of the hierarchy of needs, as it stresses the fundamental requirements of basic needs (food), which increases the satisfaction of an individual (learner). The study used a descriptive survey design with a population of 85 pre-primary schools. Headteachers were eighty-five (85) and pre-primary school teachers were one hundred and seventy (170), giving a total of 255 respondents. A sample size of 189 respondents was derived comprising of 70 headteachers and 119 pre-primary school teachers. The study employed stratified random sampling to draw respondents from the target population. The instruments used to collect data were questionnaires and interview schedules for teachers and headteachers respectively. The analysis of the collected data was done using descriptive and inferential statistics. Inferential statistics were used to show the relationship between the dependent and the independent variables and was presented in form of correlation analysis. The study findings revealed that children who are consistently provided with meals 
in school concentrated well in class activities. There existed a significant correlation $(\mathrm{p}<0.05)$ between competencies in classroom activities and school feeding programmes. The school feeding programmes enabled learners to actively participate and concentrate on school activities and enhanced competency acquisition. Some of the recommendations were that the county and national government need to fully implement the school feeding programmes and that the sustainability of the programme is vital to increased competency acquisition rate among Pre-Primary school learners.

\section{APA CITATION}

Langat, B. K., Tabot, B. A., \& Rotumoi, J. (2020). Influence of School Feeding Programme on Acquisition of Competencies in Class Activities Among Pre-Primary School Pupils in Belgut Sub-County, Kenya. East African Journal of Education Studies, 2(1), 211-219. https://doi.org/10.37284/eajes.2.1.259

\section{CHICAGO CITATION}

Langat, Benson Kiprotich, Benedicta Aiyobei Tabot, and Joseph Rotumoi. 2020. "Influence of School Feeding Programme on Acquisition of Competencies in Class Activities Among Pre-Primary School Pupils in Belgut Sub-County, Kenya". East African Journal of Education Studies 2 (1), 211-219. https://doi.org/10.37284/eajes.2.1.259.

\section{HARVARD CITATION}

Langat, B. K., Tabot, B. A. and Rotumoi, J. (2020) "Influence of School Feeding Programme on Acquisition of Competencies in Class Activities Among Pre-Primary School Pupils in Belgut Sub-County, Kenya", East African Journal of Education Studies, 2(1), pp. 211-219. doi: 10.37284/eajes.2.1.259.

\section{IEEE CITATION}

B. K. Langat, B. A. Tabot, and J. Rotumoi, "Influence of School Feeding Programme on Acquisition of Competencies in Class Activities Among Pre-Primary School Pupils in Belgut Sub-County, Kenya”, EAJES, vol. 2, no. 1, pp. 211-219, Mar. 2020.

\section{MLA CITATION}

Langat, Benson Kiprotich, Benedicta Aiyobei Tabot, and Joseph Rotumoi. "Influence of School Feeding Programme on Acquisition of Competencies in Class Activities Among Pre-Primary School Pupils in Belgut Sub-County, Kenya". East African Journal of Education Studies, Vol. 2, no. 1, Mar. 2020, pp. 211-219, doi:10.37284/eajes.2.1.259.

\section{INTRODUCTION}

School Feeding Programmes (SFPs) are common in both developing and industrialized countries of the world, (Ekundayo, Aliyu \& Jolly, 2007). The objective of School Feeding Programmes is to provide learners with a snack or meals in order to reduce short-term hunger among learners in school for them to concentrate and learn better. In addition, it aims at encouraging learners to actively participate in curricular and co-curricular activities. According to Ahmed (2004), children affected by hunger and malnutrition as well as ill-health did not have the same potential to do well at school in comparison with well-nourished and healthy children. Poor health and malnutrition lowered children's cognitive development and performance through physiological changes or reduced capacity to participate in learning activities or both (Mohamed, 2015).
The government through the Kenya Institute of Curriculum Development (KICD) revised the school curricular into the Competence-Based Curriculum (CBC), (KICD, 2017). This aimed at equipping learners with sufficient knowledge and life skills for them to survive intellectually and socially in the modern world" (Kitta \& Tilya, 2010). Effective implementation of CBC requires the active participation of learners which can be affected by short term hunger in school (Chepkwony, Kosgei \& Kariuki, 2013).

The $\mathrm{CBC}$ represents a positive step in raising living standards among the people, however, there are challenges which may negatively affect the full realization of its benefits, one of them being short term hunger among school-going children (Kosilei, Omundi \& Aseta, 2018). For quality education to be realized, learners should be well motivated which can be achieved through the provision of meals in schools. This should start at pre-primary 
schools as they act as a springboard for the upper levels of education. School Feeding Programmes (SFPs) are thus essential for quality education to be realized. When there is no provision of meals to children in school, they lack the energy to concentrate in the classroom and co-curricular activities. It also weakens their intellectual ability and contributes to incompetence among the learners (Murungi, 2011).

Good nutrition plays crucial roles in children's learning both at home and in school as reflected by their class performance and participation in cocurricular activities (Kitta \& Tilya, 2018). Hunger and malnutrition are common in most developing countries, Kenya included. Most households are food insecure and children in those households usually go to school on empty stomachs" (Chelangat, 2016). In many public pre-primary schools, provision of meals to learners is a challenge as most of those who take their children to public schools have low sources of income. They cannot even provide food with necessary nutrients to their children as compared with those who take their children to private schools (Rong'uno, 2017). Short term hunger has been a barrier to classroom concentration among pre-primary school children, which can negatively affect their level of competency. A hungry child cannot only lack concentration in class but also cannot participate well in co-curricular activities. School Feeding Programme (SFP) encourages learning as it motivates and energizes learners to learn effectively (WFP, 2017).

In 2009, the government introduced the homegrown school feeding programme in order to involve and empower the community in the provision of school food to support school access and retention of their children in schools (Langinger, 2011). Although many studies have been carried out to analyze the impact of school feeding programme on education (Rukmani, 2011 \& Songa, 2011), little has been done after the introduction of the $\mathrm{CBC}$ in Kenya. Hence this study aimed to find out the influence of SFP on the acquisition of competencies among pre-primary school learners in Belgut Sub-County. According to the Kericho County Supplementary Appropriation Act, 2017 (KCSAA), some money was set aside to cater for School Feeding Programme for ECDE children in public ECDE schools. The government supports the SFPs (WFP, 2019) and thus there is a need to find out whether there is a relationship between School Feeding programme and acquisition of competencies among pre-primary school learners.

School Feeding Programme (SFP) is crucial for quality education to be realized. Having a full stomach helps learners to concentrate better in various school activities (Evaristo, 2015). According to WFP (2004), SFPs are implemented with the aim of reducing short-term hunger and improving class concentration among the learners. Most pupils in public schools come from lowincome families where getting a meal is more of a privilege than a basic need. They are not provided with meals in school due to limited resources, while those in private schools are provided with meals (Rong'uno, 2017). Earlier studies have also indicated that when one is hungry, he/she has limited concentration, and tend to become tired often which eventually affects his/her mental, physical and emotional growth and development (Evaristo, 2015).

In Kenya, a study conducted in 2008 in Mwala division, Machakos County concluded that school feeding programme improves the performance of pupils (Wambua, 2008) but Obonyo (2009) in Yala division in Busia County contradicted the belief and expectations by concluding that school meals do not affect pupils' performance.

Private pre-primary schools have also been noted to outshine their counterparts from public schools in terms of learners' competencies (Chepkwony, Kosgei \& Kariuki, 2013). The current CBC emphasizes the acquisition of competencies among the learners which requires learners' engagement in both classroom and out of class activities yet hunger has been noted to limit the learners' concentration ability. It, however, remains unclear whether School Feeding Programme has an influence on the acquisition of competencies among the learners in pre-primary schools. This study, therefore, sought to fill the gap by assessing the School Feeding Programme and its influence on the acquisition of competencies in classroom activities among preprimary school learners in Belgut Sub-County. 


\section{LITERATURE REVIEW}

\section{Theoretical Framework}

This research study was guided by Abraham Maslow's theory of human needs (1943). The theory postulates that there are essential needs that must be met for decent standards of living. These requirements are called physiological needs which include clothing, shelter and food. Physiological need is a concept that was derived to explain and cultivate the foundation for motivation. This concept is the main physical requirements for human survival. This means that Physiological needs are universal human needs. Physiological needs are considered the first step in internal motivation according to Maslow's hierarchy of needs. This theory states that humans are compelled to fulfil these physiological needs first in order to pursue intrinsic satisfaction on a higher level. If these needs are not achieved, it leads to an increase in dissatisfaction within an individual.

\section{Empirical Review}

Games activities were measured by comparing scores in football and netball at the beginning and the end of the school year. The study found that children in primary schools with a feeding programme performed better in co-curricular activities than those in schools without hence the need for a study at the pre-school level. When looking for a possible explanation for such a positive relationship between performance and the existence of an SFP, the research identified two possibilities; that there was improved nutrition of children because of SFP and performance in cocurricular activities was good in those schools. Provision of meals in school provides pre-primary school children with energy development, which improves performance in all learning areas (Mugambi, 2011).

According to the Kenya Institute of Curriculum Development (KICD, 2017), co-curriculum activities are core in children growth and development. It is through outdoor activities that learners acquire competencies required. For learners to participate fully in these activities they need energy and thus the school feeding programme is crucial. Involvement in indoor games will build those social skills in the learner associated with team sports such as reliability, conflict resolution, confidence and positive selfimage, hard work, dedication to task, self-control, and teamwork. These skills and more will be developed and strengthened as the learner solves problems, interact with others and accomplishes set goals." Hungry children would not participate in co-curriculum activities since it affects their strength. Most of the developing countries have tried their best to offer school programmes to sustain the physical as well as the education needs of children (Ven \& Chou, 2003).

According to Khatele, Pendo, and Oyabi (2013), the school feeding programme showed improved participation in co-curriculum activities. The "curriculum in outdoor pursuits education focuses on areas such as organization of outdoor expeditions, low and construction of outdoor shelters. Involvement in outdoor pursuit education develops in the learner social skills such as resilience, hard work, self-control, reliability, conflict resolution, confidence, positive self-image, dedication, consistency, community service and determination" (KICD, 2017).

According to Matengo (2016), School Feeding Programme assisted children to participate in school programmes in Kisumu East Sub-County. Many studies have linked SFP to good health, including better memory and concentration in various activities including co-curriculum. The level of competency is high, mainly in early childhood development education that provides meals in schools. Additionally, the WFP report contended that pupils who are in schools which provide daily meals perform well in school (WFP, 2017).

Mutua (2013) noted that the school feeding program had some general objectives to achieve stabilizing pupils' attendance was one of them. Levinger (2000) suggest evidence that school feeding programmes may be most active in meeting their attendance related objectives in settings where attendance is already enough and where children come from rural relatively low social-economic backgrounds. All these studies also point to the need for programme regularities. 
Ahmed (2004) has established that school Feeding Programme has been successful in increasing pupils' performance while Obonyo (2009) in Yala division in Busia County contradicted the belief and expectations by concluding that school meals do not affect pupils' performance. These studies were conducted in primary school level hence the need for a study in pre-primary school knowing that the new CBC curriculum places a lot of emphasis on learner's engagement in activities for acquisition of competencies.

\section{Identification of Knowledge Gap}

A study done by Ahmed (2004) revealed "that school feeding program has been successful in increasing pupils' performance. A study done in Ghana on the National School Feeding Programme implemented in Ghanaian basic schools showed a positive effect on school enrolment and school academic performance (Abotsi, 2013). A study conducted in 2008 in Mwala division, Machakos county concluded that school feeding program improves the performance of pupils (Wambua, 2008) but Obonyo (2009) in Yala division in Busia county concluded that school meals do not affect pupils' performance."

According to Matengo (2016), school feeding programme assists children to participate in school programmes in Kisumu East Sub-County. Many studies have linked SFP to good health, including better memory and concentration in various activities including co-curriculum. The level of competency is high, mainly in early childhood development education centres that provide meals in schools. Additionally, the WFP report contended that pupils who are in schools which provide daily meals perform well in school (WFP, 2017). There has been no study which points out issues on CBC in preschool since most of the studies have been done at primary level, and that no study had been done in the region where the studies were done relating to specific competencies in the current study.

\section{RESEARCH METHODOLOGY}

In this study, the researcher adopted a descriptive survey design employing both quantitative and qualitative study approaches. The study was carried out in Belgut Sub-County which is one of the subcounties in Kericho country with schools having SFPs and others without. The target population of this study comprised of 85 pre-primary school headteachers, and 170 teachers giving a total of two hundred and fifty-five (255). The sample of 70 headteachers and 119 teachers. The study employed stratified random sampling method to draw respondents from the various schools. The data was collected using questionnaires for teachers and interview schedule for the headteachers. The questionnaire was appropriate for this study due to its low cost and its ability to enable the researcher to gather a considerable amount of data at a considerable amount of time. An interview guide was constructed for headteachers to seek information on the influence of SFP on learners' acquisition of competencies in classroom and cocurricular activities. The questionnaires were administered to the sampled teachers of the sampled schools. Both descriptive statistics and inferential statistics were used to analyze quantitative data. Descriptive statistics entailed the use of frequencies, percentages, means and Standard Deviation (SD) to give the overall description of the opinions of the respondents. The data from the interview schedule were presented in prose form.

\section{RESULTS AND DISCUSSION}

The study was to establish the influence of school feeding programme on the acquisition of competencies in classroom activities among preprimary school learners. Respondents were asked to rate the extent to which they agreed that school feeding programme contributed to the acquisition based on specific classroom activities. Their responses were presented on a Likert scale of 1 to 5 where 1 was strongly disagree and 5 was strongly agreed. The responses are presented in Table 1 . 
Table 1: Acquisition of Competencies in Classroom Activities

\begin{tabular}{|c|c|c|c|c|c|}
\hline School feeding programmes & $\mathbf{1}$ & 2 & 3 & 4 & 5 \\
\hline $\begin{array}{l}\text { School feeding programme enables pupils to play with } \\
\text { toys, sand and water as well as construction game with } \\
\text { ease. }\end{array}$ & $\begin{array}{l}5 \\
(4.8 \%)\end{array}$ & $\begin{array}{l}6 \\
(5.7 \%)\end{array}$ & $\begin{array}{l}3 \\
(2.8 \%)\end{array}$ & $\begin{array}{l}44 \\
(41.9 \%)\end{array}$ & $\begin{array}{l}47 \\
(44.8 \%)\end{array}$ \\
\hline $\begin{array}{l}\text { With school feeding program in place, pupils can } \\
\text { draw, paint, model, and perform practical and } \\
\text { household activities. }\end{array}$ & $\begin{array}{l}7 \\
(6.7 \%)\end{array}$ & $\begin{array}{l}8 \\
(7.6 \%)\end{array}$ & $\begin{array}{l}2 \\
(1.9 \%)\end{array}$ & $\begin{array}{l}46 \\
(43.8 \%)\end{array}$ & $\begin{array}{l}42 \\
(40.0 \%)\end{array}$ \\
\hline $\begin{array}{l}\text { School feeding programme enables pupils to audition, } \\
\text { play musical games and songs. }\end{array}$ & $\begin{array}{l}6 \\
(5.7 \%)\end{array}$ & $\begin{array}{l}9 \\
(8.6 \%)\end{array}$ & $\begin{array}{l}3 \\
(2.8 \%)\end{array}$ & $\begin{array}{l}47 \\
(44.8 \%)\end{array}$ & $\begin{array}{l}40 \\
(38.1 \%)\end{array}$ \\
\hline $\begin{array}{l}\text { Communication and creative activities such as stories, } \\
\text { memorization, working with books, reading images } \\
\text { has been enhanced through school feeding programme }\end{array}$ & $\begin{array}{l}8 \\
(7.6 \%)\end{array}$ & $\begin{array}{l}8 \\
(7.6 \%)\end{array}$ & $\begin{array}{l}2 \\
(1.9 \%)\end{array}$ & $\begin{array}{l}50 \\
(47.6 \%)\end{array}$ & $\begin{array}{l}37 \\
(35.3 \%)\end{array}$ \\
\hline $\begin{array}{l}\text { Awareness activities in the form of observations, } \\
\text { readings by pictures, mathematical activities, talks, } \\
\text { didactic games, and experiments have been improved } \\
\text { thanks to the school feeding programme }\end{array}$ & $\begin{array}{l}10 \\
(9.6 \%)\end{array}$ & $\begin{array}{l}5 \\
(4.8 \%)\end{array}$ & $\begin{array}{l}3 \\
(2.8 \%)\end{array}$ & $\begin{array}{l}44 \\
(41.9 \%)\end{array}$ & $\begin{array}{l}43 \\
(40.9 \%)\end{array}$ \\
\hline
\end{tabular}

\section{Source: Research Data (2020)}

Table 2 reveals that majority of the respondents 91 $(86.7 \%)$ agreed that school feeding programme enables pupils to play with toys, sand and water as well as construction games with ease. Eleven (11) respondents representing $(10.5 \%)$ disagreed while $3(2.8 \%)$ of the respondents were undecided. With school feeding programme in place pupils can draw paint, model, carry out practical and household activities since majority of the respondents 88 $(83.8 \%)$ agreed to it, $15(14.3 \%)$ respondents disagreed to it while only $2(1.9 \%)$ of the respondents were undecided.

Majority of the respondents 87 (82.9\%) according to Table 4.7 agreed that school feeding programme enables pupils to audition, play musical games and songs. The respondents who disagreed that the school feeding programme enables pupils to audition, play musical games and songs were 15 $(14.3 \%)$ while 3 (2.8\%) respondents were undecided.

Communication and creative activities such as stories, memorization, working with books, reading images has been enhanced through the school feeding programme since the majority of the respondents $87(82.9 \%)$ agreed to it. Respondents who disagreed that communication and creative activities such as stories, memorization, working with books, reading images have been enhanced through school feeding programme were 16
(15.2\%) while 2 (1.9\%) respondents were undecided.

Majority of the respondents who were 87 (82.9\%) agreed that awareness activities in the form of observations, readings by pictures, mathematical activities, talks, didactic games, experiments had been improved because of school feeding programme whereas $15(14.3 \%)$ respondents disagreed while 3 (2.8\%) respondents were undecided. The findings show that school feeding programme enables pupils to acquire classroom activities-skills such as playing with toys, symbolic play and sensorial games, playing with sand and water, construction games, and didactic games. Artistic skill activities such as drawing, painting, modelling, practical and household activities were enhanced through the SFP as well as music and movement activities comprising of auditions, musical games, text games and singing songs.

It is evident that the SFP also influenced learners' participation in communication and creative activities which encompass stories, memorization, working with books, and reading images. This was also apparent in awareness activities such as observations, readings by pictures, mathematical activities, talks, didactic games, and experiments.

The researcher observed the pupil's classroom behaviour in a number of academic tasks, namely; picture reading, colours, sorting and grouping 
objects by size, sorting and grouping objects by shape, number recognition and alphabets measurement of length by pacing. Their performance as observed was measured in a threepoint Likert scale ranging from; totally unable (0), able with assistance (1) and able without assistance (2). The maximum score was 16 and the minimum score was zero. The mean scores of the parameters under investigation included for schools with and without a feeding programme respectively were; reading sounds $(14,10.5)$, picture reading $(10,9.5)$, colours $(11,9.5)$, alphabets $(14,12)$, sorting and grouping by size $(10,6)$, sorting and grouping by shape $(11,5)$ number recognition $(13,9)$ and measurement of length by pacing $(8,7)$. These findings indicate that the pupils in schools with a feeding programme were performing much better compared to those without. The increased school participation due to SFPs leads to learner attentiveness, motivation, physiological comfort, and increased readiness to learn hence positively impacting on their acquisition of competencies. In addition, a hungry child is dull and less active reducing their interaction in the classroom and in co-curricular activities.

The findings are consistent with WFP (2010) which points out that SFP is mainly introduced to improve their performance through acquisition of competencies rather than to increase enrolment. The study findings also agree with Maslow's theory of the hierarchy of needs which states that the physical needs such as food ought to be met before moving to higher needs in the hierarchy. This implies that those children whose needs are met through SFP are contented and happy since the learning environment is conducive hence acquire relevant competencies easily.

Relationship between variables is a measure of how well the variables are linearly related and was measured using correlation analysis. The study examined how the predictor variables (classroom activities) were related to the dependent variable (school feeding programme). The results are presented in Table 2.

Table 2: Correlations

\begin{tabular}{lllc}
\hline & & Classroom Activities School & Frogram \\
Plassroom Activities & Pearson Correlation & 1 & \\
& Sig. (2-tailed) & & 1 \\
\hline School Feeding Program & Pearson Correlation & $.337^{* *}$ & \\
& Sig. (2-tailed) & .001 & \\
\hline
\end{tabular}

**. Correlation is significant at the 0.05 level (2-tailed).

Source: Research Data, (2020)

The results in Table 1 shows that a significant correlation exists between classroom activities and school feeding programme in Belgut Sub - County $(\mathrm{r}=0.337, \mathrm{p}<0.05)$.

\section{CONCLUSIONS AND RECOMMENDATION}

\section{Conclusions}

School Feeding Programme (SFP) enhances enrolment and daily attendance by children; creates a conducive environment for smooth transition from home to preschool and that it enhances the learners' involvement in learning activities. There is need to have parents and the government do cost- sharing in the school feeding programme since Though it was often expensive to implement SFP programmes in schools, the pupils in schools with a feeding programme were performing much better compared to those without. It also increased school participation and that it positively impacted on the acquisition of competencies

School feeding programme influences learners' participation in communication and creative activities which encompass stories, memorization, working with books, and reading images. An increase in school feeding programme increases acquisition of competencies in classroom activities and co-curricular activities and acquisition of 
competencies in classroom activities. School feeding programme has a positive and statistically significant relationship with the acquisition of competencies.

\section{Recommendations}

From the findings, the researcher recommends the following strategies for improvement or better management of the programme in the Sub-County.

- School Feeding Programme (SFP) should be made compulsory in all pre-primary school and where possible parents and the government do cost-sharing since it enhances acquisition of competencies in both class and out-of-class activities.

- There is need to increase the number of meals offered and be of a different kind under school feeding programme so that learners get the required nutrients since it increases their acquisition of competencies in classroom activities and co-curricular activities.

- Capacity-building should be continuous and mandatory for all programme Managers for effective and efficient management of the programme.

\section{REFERENCES}

Abotsi A. K. (2013). Expectations of School Feeding Programme: Impact on School Enrolment, Attendance and Academic Performance in Elementary Ghanaian Schools. British Journal of Education, Society \& Behavioural Science, 3(1), 76-92.

Ahmed, A. U. (2004). Impact of feeding children in school: Evidence from Bangladesh. Washington, DC: International Food Policy Research Institute.

Chelangat, C. (2016). Influence of School Feeding Programme on school attendance and enrolment. Nairobi: Kenyatta University.

Chepkwony, B. C., Kosgei, L. J., \& Kariuki, B. M. (2013). School feeding program and its impact on academic achievement in ECDE in Roret Division, Bureti District in Kenya. Journal of
Emerging Trends in Educational Research and Policy Studies, 4(3), 407-412.

Ekundayo, O. J., Aliyu, M. H., \& Jolly, P. E. (2007). A review of intestinal helminthiasis in Nigeria and the need for school-based intervention. Journal of Rural and Tropical Public Health, 6(1), 33-39.

Evaristo, M. C. (2015). An assessment of influence of school feeding program on pupils' enrolment, attendance and academic performance in primary schools in Njombe district, Tanzania. Unpublished Master's Thesis.

Kenya Institute of Curriculum Development. (2017). Report on Needs Assessment for ECDE School Curriculum Reform in Kenya. Nairobi: KICD.

Khatete, I. W., Pendo, S., \& Oyabi, J. M. (2013). School feeding program and pupils' participation in primary schools in Kenya. A study of Taita Taveta and Nairobi Districts. Journal of Emerging Trends in Educational Research and Policy Studies, 4(6), 895-900.

Kitta, S., \& Tilya, F. (2018). Assessment Status of Learner-centred Learning in Tanzania in the Context of the Competence-based Curriculum. Papers in Education and Development, (29).

Kosilei, J., Omundi, E., \& Aseta, J. (2018). Effects of Feeding Programme on Enrolment Rates and Retention in Public ECD Centres in Sigor Division, Chepalungu District, Bomet County, Kenya. European Journal of Education Studies, 4(6), 101-113.

Langinger, N. (2011). School feeding programs in Kenya: Transitioning to a homegrown approach. Stanford Journal of International Relations, 13(1), 30-37.

Levinger, B. (2005). School feeding, school reform, and food security: Connecting the dots. Food and Nutrition Bulletin, 26(2), 170-178.

Maslow, A. H. (1943). A theory of human needs. Psychological Review, 50, 370-396.

Matengo, L. A. (2016). Influence of school feeding programme on children's 'participation in pre- 
school in Kisumu east Sub-County, Kenya (Doctoral dissertation, University of Nairobi).

Mohamed, A. O. (2015). Influence of feeding programs on the participation of learners at early childhood development education institutions: A case of Bungoma South District. International Academic Journal of Social Sciences \& Education, 1(4), 1-14.

Mugambi, V. (2011). The impact of the Preschool feeding programme on performance of Preschool children in Kangeta division, Meru County, Eastern province (Doctoral dissertation, University of Nairobi, Kenya).

Murungi, C. G. (2011). Children's Basic Needs and Enrolment in Early Childhood Education in Miriga Meru West Division. Unpublished Ph. D Thesis. Kenyatta University.

Mutua, D. S. (2013). Influence of School Feeding Program on Pupils' Participation in Public Primary Schools in Masinga Division in Machakos County, Kenya (Doctoral dissertation, University of Nairobi,).

Obonyo, J. A. (2009). Effects of School Feeding Program on Pupils' Participation in Public Day Primary Schools in Yala Division Kenya (Doctoral dissertation, University of Nairobi).

Rong'uno, S. K. (2017). A comparison of academic performance between public and private secondary schools in Wareng District, Kenya. British journal of education, 5(11), 58-67.

Rukmani, R. (2011). The School Feeding Program in India.

Songa, W. (2011, February). School Feeding Programs in Kenya. In Leveraging Agri. Improved Nutr. Health, Int. Conf (pp. 10-12).

Wambua, P. K. (2008). The Role of School Feeding Program in Promoting Enrolment and Retention in Primary Schools in Mwala District in Kenya.

World Food Program. (2004). School feeding program: Why they should be scaled up now? Dar es salaam: WFP.
World Food Program. (2017). Impact Evaluation of WFP School Feeding Programmes. Geneva: Office of Evaluation of the World Food Programme.

World Food Program. (2019). Annual Report on funding and donors, Nutrition and Zero Hunger. Geneva: Office of Evaluation of the World Food Program. 